\title{
Federal Licensing and Atomic Energy
}

\author{
Dean C. Dunlavey*
}

Since passage of the Atomic Energy Act of $1954,{ }^{1}$ industry has participated to a progressively increasing extent in the development and utilization of nuclear energy. Such participation, however, is dependent in large part upon approbation received from the Atomic Energy Commission under a statutory licensing scheme.

In dealing with some governmental agencies, for example the Securities and Exchange Commission or the United States Patent Office, industry is primarily represented by attorneys. To date, this has not been the case in licensing of industry by the Atomic Energy Commission. Most licensing has been effected by the AEC after negotiating with and receiving applications from the scientific and technical personnel of industry. It now appears that the attorney's place in nuclear energy licensing will be limited largely to the conduct of hearings in contested cases where a license application is acted upon unfavorably by the Commission and in cases where a license, once issued, is thereafter threatened with suspension, modification or revocation by the Commission.

The federal licensing scheme in the nuclear energy field is based on various congressional findings in the Atomic Energy Act of 1954 to the effect that nuclear materials and the facilities which produce or use them are affected with the public interest and that their utilization affects interstate and foreigu commerce and must be regulated in the national interest and in order to provide for the common defense and security and to protect the health and safety of the public. ${ }^{2}$

IICENSING

Commission licenses are of three general types. The first type hicense is required for the possession or use of various kinds of nuclear materials. The second type is required for possession or use of a facility which produces or utilizes certain of these nuclear materials. The third type is required for persons who operate such facilities.

\section{A. Nuclear Material Licenses}

One general category of nuclear materials licensed by the Commission is called "source material"; these are materials which are sources from

* Member, Los Angeles Bar.

168 STAT. 919 (1954), as amended, 42 U.S.C. \$§ 2011-281 (Supp. IV 1956).

2 Atomic Energy Act of 1954, § 2, 68 STar. 921, 42 U.S.C. § 2012 (Supp. IV 1956). 
which several energy-producing nuclear materials, called "special nuclear material," can be obtained. By current statutory definition, source material means uranium or thorium; ${ }^{3}$ by regulation, it includes any material which contains by weight $.05 \%$ or more of these, either separately or in combination. ${ }^{4}$ Although the statute is not specifically worded to indicate that source material denotes uranium and thorium ${ }^{5}$ as they occur in nature, this is accepted as its meaning. Source material includes these naturally occurring elements in whatever state they may be found, ranging from raw ore to refined metal.

A specific or general license is required to "transfer or receive in interstate commerce, transfer, deliver, receive possession of or title to, or import into or export from the United States any source material after removal from its place of deposit in nature"-except quantities deemed unimportant by the Commision. ${ }^{6}$ A source material license can be obtained for certain enumerated uses and also for any other use approved by the Commission as an aid to science or industry. ${ }^{7}$ Although development of a natural uranium power reactor is being undertaken, source material presently has no large scale use as such by private industry. Source material licenses currently are issued primarily to permit various activities requisite to production and purification of such material, preparatory to obtaining or making special nuclear material from it.

Source material is readily obtainable by virtually any nation, either from its own natural resources or by acquisition on the international market. The material is in abundant supply and there may be doubt that it presents any particular need for regulation in the interest of national defense or security, other than might arise from uncontrolled export. Except as used in reactors, the material presents minimal health and safety considerations because of the low intensity of its natural radioactivity.

The second category of nuclear materials licensed by the Commission is "special nuclear material." Materials currently included in this category are primarily valued for their fission properties which result in the release of energy. There now are three special nuclear materials: plutonium, uranium 233 and uranium enriched in the isotope 233 or in the isotope $235 .^{8}$ The process of making or obtaiming special nuclear material from source material is an expensive one, as can be seen by comparing the cost of natu-

\footnotetext{
3 Atomic Energy Act of 1954, § 11s, 68 STAT. 924, 42 U.S.C. $\$ 2014$ (x) (Supp. IV 1956), redesignated $\S 11 \mathrm{x}$ by 71 StAT. 576 (1957).

410 C.F.R. § 40.2(a) (1949).

5 Uranium $235(.71 \%)$, uranium $238(99.28 \%)$, and thorium $232(100 \%)$.

${ }^{6}$ Atomic Energy Act of 1954, § 62, 68 StAT. 932, 42 U.S.C. § 2092 (Supp. IV 1956).

7 Atomic Energy Act of 1954, § 63, 68 Star. 933, 42 U.S.C. \& 2093 (Supp. IV 1956).

8 Atomic Energy Act of 1954, § 11t, 68 STat. 924, 42 U.S.C.A. \$ 2014(y) (Supp. 1957), redesignated § 11y by 71 STAT. 576 (1957); 10 C.F.R. \& 70.4(m) (Supp. 1956).
} 
ral uranium metal, at about $\$ 18.00$ a pound, with the cost of uranium 235 metal, at nearly $\$ 8,000.00$ a pound.

There are two absolute prohibitions on private dealings in special nuclear material-there can be no private ownership ${ }^{9}$ and there can be no private import into or export from the United States. ${ }^{10}$ In addition, a specific or general license is required to possess or transfer any special nuclear material owned by the government, or to transfer or receive any special nuclear nuaterial in interstate commerce. ${ }^{11}$ At present, special nuclear material is available to industry for limited purposes only. These purposes may be for academic or industrial researcl and development, for medical therapy, or for use only in production or utilization facilities as these are defined by the Commission. ${ }^{12}$,

The Government is the owner of, and sole source of supply for, special nuclear material in the United States. ${ }^{13}$ To date, the President has allocated a total of 50,000 kilograms-approximately 50 tons-for domestic use. Eacl licensee's total requirements are reserved by deduction from this amount. ${ }^{14}$ If all the domestic allocation of material slould be thus reserved, the Commission then would have either to obtain further allocation or to cease further licensing. There might appear to be some question of fairness if allocated amounts of special nuclear material are denied for one applicant's present use because reserved for a prior hicensee's future use. On the other hand, it must be recognized that the prior licensee is entitled to assurance that all of the material promised to him will be made available. However, as a practical matter, the sum of 50,000 kilograms has been allocated with the intention that it will be delivered partially in the future. Purportedly, the Commission currently does not have on hand 50,000 kilograms of special nuclear material for domestic use, but rather is promising to licensees material which it expects to be able to make available in the future as needed.

Special nuclear material is the basic ingredient of fission-type nuclear weapons and obviously affects the country's common defense and security. In addition, plutonium presents serious health and safety problems from a chemical standpoimt; also, use of any special nuclear.material presents serious health and safety problems arising from intense radiation.

The third category of nuclear materials licensed by the Commission is

${ }^{8}$ Atomic Energy Act of 1954, § 52, 68 STAT. 929, 42 U.S.C. § 2072 (Supp. IV 1956).

10 Atomic Energy Act of 1954, §57a(2), 68 STAT. 932, 42 U.S.C. $\$ 2077$ (a) (2) (Supp. IV 1956).

11 Atomic Energy Act of 1954, §§ 53a, 53b, 57, 68 STAT. 930, 932, 42 U.S.C. $\S \S 2073$ (a), 2073(b), 2077 (Supp. IV 1956).

12 Atomic Energy Act of 1954, §53a, 68 Star. 930, 42 U.S.C. $\$ 2073$ (a) (Supp. TV 1956).

${ }_{13}$ Atomic Energy Act of 1954, § 52, 68 StAT. 929, 42 U.S.C. $§ 2072$ (Supp. IV 1956).

1410 C.F.R. $\$ 50.60$, note (Supp. 1956). 
"byproduct material," so called because such materials are produced as a by-product in the course of producing or utilizing special nuclear material. The category encompasses any radioactive material except special nuclear material "yielded in or made radioactive by exposure to the radiation incident to the process of producing or utibizing special nuclear material."15 This definition extends to virtually countless radioactive substances and could include a radioactive form of practically any conceivable material.

A specific or general license is required to "transfer or receive in interstate commerce, manufacture, produce, transfer, acquire, own, possess, import, or export any byproduct material." Byproduct material can be licensed for any useful application. ${ }^{16}$

Extreme health and safety problems can arise from the high levels of radioactivity associated with many byproduct materials. Public concern with the dangers of radiation popularly is focused on nuclear reactors. Equal or greater concern should be devoted to the ever increasing widespread use of byproduct materials, often under conditions where safety precautions may be stressed less than in the operation of reactors.

\section{B. Facility and Operator Licenses}

A facility, for which the act requires a license, is "any equipment or device" which is determined by rule of the Commission to be capable of producing or using special nuclear material, or using atomic energy, in such quantity as to be of significance to the common defense and security, or in such manner as to affect the health and safety of the public. ${ }^{17}$

The broad terms "equipment or device" as used in the act have been limited by the regulations. A production facility is limited, by regulation, to: ${ }^{18}$

(1) Any nuclear reactor designed or used primarily for the formation of plutonium or uranium 233; or

(2) Any facility designed or used for the separation of the isotopes of uranium or isotopes of plutonium, except laboratory scale facilities ... ; or

(3) Any facility designed or used for the processing of irradiated materials containing special nuclear material, except laboratory scale facilities

while a utilization facility is limited to: ${ }^{19}$

$\ldots$ any nuclear reactor other than one designed or used primarily for the formation of plutonium or U-233.

${ }^{15}$ Atomic Energy Act of 1954, § 11e, 68 StaT. 923, 42 U.S.C. § 2014(e) (Supp. IV 1956).

16 Atomic Energy Act of 1954, § 81, 68 StaT. 935, 42 U.S.C. \& 2111 (Supp. IV 1956).

${ }_{17}$ Atomic Energy Act of 1954, $\S 11$ p, 11v, 68 STAT. 923, 924, 42 U.S.C.A. $\$ \S 2014$ (t), (aa)

(Supp. 1957), redesignated §§ 11t, aa by 71 STAT. 576 (1957).

1810 C.F.R. $\$ 50.2$ (a) (Supp. 1956).

1910 C.F.R. $\$ 50.2$ (b) (Supp. 1956). 
A license is required "to transfer or receive in interstate commerce, manufacture, produce, transfer, acquire, possess, use, import, or export any utilization or production facility. ${ }^{.20}$ A facility may be either (1) of a research and development kind, commonly called a section 104 facility, or (2) a commercial device having practical value, commonly referred to as a section 103 facility. Most facilities to date are of the section 104 type. The use of nuclear facilities affects the common defense and security of the nation and the public health and safety in much the same manner heretofore described for special nuclear material.

It has been noted that the regulations define a production or utilization facility considerably more narrowly than would be possible under the act. A recent consequence of this narrow interpretation was that a person who wanted over $\$ 100,000$ worth of plutonium for use in commercial oil well logging devices was denied a license because, under the regulations, his commercial devices were not reactors-although they very well could be among the "equipment or devices" described by the act. After indicating its opinion that the regulations define facilities as contemplated by the spirit of the current act, the Commission advised the applicant: ${ }^{21}$

The Commission has recently submitted a recommendation to the Congress that Section 53 of the Act be amended to authorize the distribution of special nuclear material for additional uses. We will advise you when we are able to distribute plutonium to you for other than the research and experimental aspects of your well-logging activities.

In addition to the foregoing licenses, an operator's license is required for any individual who manipulates the controls of a utilization or production facility. ${ }^{22}$ Requirentents for such a license are mainly a showing of adequate mental and pliysical competence.

\section{General and Specific Licenses}

A few general licenses are provided for by regulation; that is, licenses available to the public in general without need for specific application. For practical purposes, these general licenses are of private interest only with respect to limited uses of byproduct material.

A specific license is obtained by individual application to the Division of Licensing and Regulation of the Atomic Energy Commission. License applications often are preceded by informal communication and consultation with the Commission.

In any application, the applicant is required to submit written informa-

20 Atomic Energy Act of 1954, §101, 68 StaT. 936, as amended, 42 U.S.C. § 2131 (Supp. IV 1956).

21 CCH AtOM. ENERGY I. ReP. If 7143 (1957).

22 Atomic Energy Act of 1954, § 107, 68 STAT. 939, 42 U.S.C. $\$ 2137$ (Supp. IV 1956). 
tion of his technical qualifications; that is, the skill and experience which he and his employees have in the general field of nuclear science. In addition, the applicant may be required to submit information of his financial qualification to engage in the proposed activity. Materials commonly submitted in support of this requirement include balance sheets or other financial statements such as are commonly prepared for shareholder reports. The applicant also may be required to submit information of his character and citizenship. ${ }^{23}$

Among the most important matters which must be disclosed by any application are details of the applicant's proposed activity. This information can be quite complex for facility licenses-for example, a summary of the hazards to be expected, the precautions to be taken, the manner of radioactive waste disposal, and so forth.

Because of practical difficulties in setting forth complete details of reactor operation in advance, some technical information may be provided after the issuance of a provisional construction permit (a construction permit being the first "license" received by a facility applicant) but before the issuance of an operating license. This may be done "if the Commission is satisfied that it has information sufficient to provide reasonable assurance that a facility of the general type proposed can be constructed and operated at the proposed location without undue risk to the health and safety of the public" and that the omitted information for the particular facility will be supplied thereafter. ${ }^{24}$ The construction permit is subject to later production of the omitted information and to a Commission evaluation as to the safety of the final design. Each license application, together with the action which the Commission may take in respect to it, except for restricted data contained therein, becomes available for inspection in the Public Document Room of the Commission.

Licensing procedure follows the Administrative Procedure Act. ${ }^{25}$ In the case of material licenses, the Commission normally takes action on the application without a hearing, but makes this action subject to a subsequent hearing if requested within thirty days thereafter. ${ }^{28}$ In the case of most facility license applications (power or testing facilities), a hearing is first held, after which the Commission takes its action. ${ }^{27}$ If the Commission approves the facility license application, a construction permit is issued. An operating license will be issued following another hearing if the Com-

23 Atomic Energy Act of 1954, § 182, 68 StaT. 953, as amended, 42 U.S.C. § 2232 (Supp. IV 1956).

2410 C.F.R. $\$ 50.35$ (Supp. 1956).

25 Atomic Energy Act of 1954, § 181, 68 Stat. 953, 42 U.S.C. § 2231 (Supp. IV 1956).

2610 C.F.R. $\$ 2.102$ (a) (Supp. 1956).

27 Atomic Energy Act of 1954, §189, 68 STAT. 955 as amended, 42 U.S.C.A. $\$ 2239$ (Supp. 1957). 
mission still regards the facility as safe. Judicial review is available after any action taken by the Commission. ${ }^{28}$

\section{License Restrictions}

Licenses once obtained are subject to considerable restrictions. ${ }^{29}$

\section{Inalienability.}

No license or rights thereunder shall be transferred, assigned or in any manner disposed of, either voluntarily or involuntarily, without Commission consent in writing.

\section{Modification.}

Every license shall be subject to amendment, revision, or modification, by reason of amendments to the act or Commission regulations.

Revocation, Including, by Regulation, Suspension or Modification.

Any license may be revoked, suspended or modified for any material false statement in the license application, or in any statement of fact required by the Commission, or because of conditions revealed by such application, statement of fact, or any report, record, inspection or other means which would warrant the Commission to refuse to grant a license on an original application, or for failure to construct or operate a facility in accordance with terms of a construction permit or license, or for a violation of, or failure to observe, any term or provision of the act or of any regulation of the Commission. ${ }^{30}$

In accordance with the Administrative Procedure Act, the licensee gets notice of a violation except in emergency cases. This notice normally is followed by a liearing on an order to show cause, althougli the action may be made temporarily effective in emergency cases. ${ }^{31}$

\section{Suspension.}

Any license may be suspended whenever the Congress declares that a state of war or national emergency exists, if in the judgment of the Commission such action is necessary to the common defense and security. During such period, special nuclear material may be recaptured by the Commission, or the Commission may order the operation of any facility licensed under section 103 or 104. Just compensation shall be paid for any damages caused by such recapture or operation. ${ }^{32}$

\footnotetext{
28 Ibid.

${ }^{29}$ Atomic Energy Act of 1954, $\S \S 183,184,186,18 \%, 68$ StaT. 954, 955, 42 U.S.C. $\S \S 2233$, 2234, 2236, 2237 (Supp. IV 1956).

3010 C.F.R. $\$ 40.25$ (1949), $\$ \$ 30.51,50.100$, 55.40, 70.61 (Supp. 1956).

31 10 C.F.R. part 2, subpart B (Supp. 1956).

32 Atomic Energy Act of 1954, § 108, 68 STAT. 939, 42 U.S.C. § 2138 (Supp. IV 1956).
} 
Requisition or Condemnation of Production Facilities or Source Material.

The Commission may requisition, condemn or otherwise acquire any interest in a production facility, or in real property on which such facility is located, making just compensation therefor. ${ }^{33}$ The Commission also may requisition, condemn or otherwise acquire any interest in supplies of source material or in real property containing deposits of source material, making just compensation therefor. ${ }^{34}$

\section{II}

\section{CONTESTING COMMISSION ACTION}

In the event a formal hearing is required ${ }^{35}$ to contest a Commission action concerning either a license or license application, the licensee or applicant can represent himself or can be represented by an attorney at law. Accordingly, it is in the hearing procedures that an attorney may be most apt to have contact with the Atomic Energy Commission concerning licensing.

One hearing before the Commission, initiated over two years ago, has led to several important changes in hearing procedure and provides an interesting vehicle for familiarization therewith.

\section{A. The PRDC Hearing}

On January 6, 1956, the Power Reactor Development Company-including among its members leading industrial and utility corporationsfiled an application for a license to build and operate a fast-neutron breeder power reactor, of 100,000 electrical kilowatt capacity, at a site approximately thirty miles from Detroit, Michigan and Toledo, Ohio. On August 4, 1956, the Commission issued a "provisional" construction permit, subject to a hearing if requested by an interested party within thirty days. This permit was made provisional upon further showing by the applicant of reactor safety and of the applicant's financial qualifications. On August 31, 1956, the United Auto Workers and two other Unions petitioned to intervene. This intervention was allowed on October 8, 1956, and a formal hearing ensued.

\section{Sequence of Commission Action and Hearing.}

At the time the PRDC license was issued, the Commission followed the same procedure for facility licensing as it now uses for material licensing-that is, the license action was taken without prior hearing but made

33 Atomic Energy Act of 1954, § 43, 68 Stat. 929, 42 U.S.C. $\$ 2063$ (Supp. IV 1956).

34 Atomic Energy Act of 1954, §66, 68 STaT. 933, 42 U.S.C. $\$ 2096$ (Supp. IV 1956).

35 Rules of Practice governing all proceedings before the Commission are in 10 C.F.R. Part 2 (Supp. 1956). 
subject to a subsequent hearing if requested within thirty days. Although the grounds for intervention will be considered in inore detail later, it may be noted that the intervenors' primary objection was that this particular reactor constituted a health and safety hazard to the hundreds of thousands of Union members who lived within a one hundred mile radius of the proposed site. Accordingly, the intervenors asked that the construction permit be suspended during the liearing. The Commission denied this request, stating that no nuclear liazards could arise from the mere construction of a reactor-as contrasted with its use, not then licensed.

The ground thus given by the Commission for denying suspension was in contrast to provisions in both the act and the regulations which stress that the time for gauging operating safety is before any construction permit is issued..$^{36}$ The act and the regulations stress such early inquiry as to safety so as to mimimize the possibility that an applicant may expend a considerable sum of money in construction, only to have an operating license denied for considerations of public health and safety. Even though the PRDC expressed willingness to gamble its construction investment on the likelihood that it could show ultimate safety of operation, the intervenors rationally alleged that PRDC nonetheless got a psychological advantage in that the Commission would be more reluctant to turn down its operating license after millions of dollars had been spent on construction and preparation.

Although suspension of the PRDC license was demed, marked changes in procedure for acting upon subsequent facility license applications soon were adopted, first by the Commission and then by Congress. Within two months after the commencement of the PRDC hearing, the Commission changed its policy on facility license applications and thereafter published notice of proposed action, with a period of at least fifteen days being allowed to request a hearing. The license or construction permit was to be held in abeyance during the hearing if one were requested. This procedure is still followed for research facility license applications.

Apparently feeling it was not proper to place the burden of instituting a hearing on third parties, Congress, in September, 1957, amended the act to require a hearing, after thirty days' notice, on all applications for power or testing facilities before the Commission announces its position or proposed action. ${ }^{37}$ It remains to be seen whether this requirement will result in predicted delays of civilian power reactor projects.

\section{Determination of Parties and Issues at a Hearing.}

The Commission initiates the hearing by serving notice containing a "Specification of Issues." Thereafter, answers as to these issues are filed by

${ }^{86}$ Atomic Energy Act of 1954, § 182, 68 STAT. 953, as amended, 42 U.S.C. $\$ 2232$ (Supp. TV 1956); 10 C.F.R. $\$ \$ 50.40,50.45$ (Supp. 1956).

3771 STAT. 579 (1957), 42 U.S.C.A. \& 2239 (Supp. 1957), amending Atomic Energy Act of 1954, § 189, 68 STAT. 955. 
the parties. In the PRDC case, the initial parties consisted of the applicant, the intervenor Union, and a staff from the Commission. It is notable that, although separation of function is not required in the case of initial licensing under the Administrative Procedure Act, ${ }^{38}$ the Commission deemed it desirable and used a separated staff in this first formal hearing. In essence, the hearing remained a three party affair.

The State of Michigan through its Attorney General intervened on March 4, 1957, stating, among other things, that the Governor was interested in state legislation related to atomic reactors within the state, that the Water Resources Commission was interested in water pollution and that the Department of Labor was interested in workers' safety. 'The state's petition further said that atomic energy plants should not be licensed or built within the state, nor should hearings thereon be held, without active participation of state agencies. Although it first appeared that an interesting comparison of state and federal views and authority as to the construction of nuclear reactors might be forthcoming during the hearing, the state did not act as an advocate during the hearing and eventually filed only a mild statement of position. This statement said merely that the hearing had developed matters of public health, welfare and safety, that the state neither approved nor disapproved this particular project, and that this hearing would not be a substitute for the state's own procedures. No indication was made as to what state procedures might be contemplated.

In accordance with provisions in the regulations, statements of position without intervention also were filed by several other independent private parties, who set forth their views on the hearing issues. The general tenor of these statements was to oppose the license to PRDC.

The intervenor Union's petition had been worded to allege violations of the act and regulations by the Commission in issuing the PRDC construction permit without making findings that, at the time of issuance, there was reasonable assurance of reactor safety and that PRDC was financially qualified. However, the Commission framed the issues for hearing in terms of whether, at the time of hearing, there was such reasonable assurance of reactor safety and whether the PRDC was financially qualified. The Commission put the burden of proof of these matters on PRDC. The intervenors objected strenuously to this shift in emphasis, notwithstanding that the only apparent difference in consequence in this instance would be whether the construction permit was void from inception or whether it should be revoked after being validly issued. However, the framing of issues by the Commission was intended and served to permit the factual proof to draw on research, development and circumstances which occurred after the hearing commenced.

38 Administrative Procedure Act $\S 5(c), 60$ STAT. 239, 5 U.S.C. $\$ 1004$ (c) (1952). 
The Safety Issue.

In considering one ground for intervention, the alleged absence of findings as to reactor safety during operation, it should be realized that the intent of the act is to have private industry contribute to advances in science and reactor technology. It is logical that industry will do so by constructing prototype reactors which it hopes to use commercially when completed. In this pioneering area of science many unforeseen problems of reactor operation will be encountered; many known problems can be solved only in the course of actual reactor construction. The act requires the Commission to give hicense priority to private projects leading to major advances, ${ }^{39}$ that is, projects which will add materially to the fund of knowledge and expertise. Since reactor projects leading to major advances often must be initiated while many details of operation remain unresolved, the act provides that additional information as to reactor operation can be submitted by the applicant after the construcion permit has been issued, as the work progresses. ${ }^{40}$ Thus, the act seemingly recognizes that private development would be seriously retarded if every uncertainty had to be resolved before construction could begin.

Commission regulations, which draw the line for permissible uncertainty in the compromise between scientific advance and public safety, provide for issuance of provisional construction permits "if the Commission is satisfied that it has information sufficient to provide reasonable assurance that a facility of the general type proposed can be constructed and operated at the proposed location without undue risk to the health and safety of the public and that the omitted information will be supplied...."41 From the language of this regulation, it is not difficult to foresee the unresolved ambiguity which arose in the course of the PRDC hearing as to whether this regulation means reasonable assurance that a reactor of the general type proposed could be operated safely today, or whether it means a probability of safe operation as a result of continuing research and development by the time construction is complete.

The PRDC reactor is admittedly of an especially dangerous type, commonly known as the "fast breeder reactor." Before issuing the construction permit, the Commission had received a report from its Advisory Committee on Reactor Safeguards, whicll said: "The Committee believes there is insufficient information available at this time to give assurance that the PRDC reactor can be operated at the site without public hazard." The Committee report further stated: "It appears doubtful that sufficient experimental information will be available in time to give assurance of safe

39 Atomic Energy Act of 1954, § 104b, 68 STAT. 937, 42 U.S.C. § 2134(b) (Supp. IV 1956).

40 Atomic Energy Act of 1954, § 185, 68 Star. 955, 42 U.S.C. $\$ 2235$ (Supp. IV 1956).

4110 C.F.R. $\$ 50.35$ (Supp. 1956). 
operation of this reactor unless the present fast reactor program of the AEC is amplified and accelerated."

This Advisory Committee report was not made public at the time the Commission announced issuance of the PRDC permit, but apparently it came to the attention of the intervenors. Such a report offers a valuable and objective appraisal of a proposed reactor and would be of substantial interest to anyone who might be interested in possible intervention. Probably for this reason, at least in part, Congress has now changed the statute to require that such reports be made public in advance of Commission action, ${ }^{12}$ thus giving interested persons the benefit of expert opinion as to the safety of a proposed reactor project and affording them the chance to make a more intelligent determination as to whether intervention is desirable.

\section{The Financial Issue and Proper Scope of Intervention.}

The intervenors also challenged the adequacy of PRDC's financial qualifications under requirements of the act and regulations. ${ }^{43}$ The requirements in the law pertaining to an applicant's financial qualifications are intended, in part, to assure that the applicant can meet the government's charges for special nuclear material and that projects to which the government has contributed money or services will be carried to completion. It can be seen that the interest of an intervenor in PRDC's financial status is not as clear as that in the safety of its reactor.

The adequacy of PRDC's proposed financial situation during the period of reactor operation is especially dependent upon income from a government buy-back of special nuclear material produced by the reactor. The intervenors alleged that changes in the government buy-back program easily could render PRDC's financial program inadequate. PRDC pointed out that its firm financial arrangements were sufficient to give reasonable assurance of meeting costs of construction, which was all that had been licensed to date. PRDC further pointed out the impracticality of projecting the financial picture on a firm basis as to the period of ultimate operation, but said that its substantial membership was sufficient indication of its financial capabihty as to this matter.

PRDC also moved to strike this issue, on grounds that it was a matter of concern only as to PRDC and the Commission and that the intervenors lad no interest in it. The Commission acknowledged that there was an important question of how much an intervenor could challenge after once establisling an interest in the hearing. However, in this case, the Commis-

4271 STAT. 579 (1957), 42 U.S.C.A. \$2232(b) (Supp. 1957), amending Atomic Energy Act of 1954, § 182, 68 STAT. 953.

43 Ibid.; 10 C.F.R. $\$ \$ 50.40,50.60$ (Supp. 1956). 
sion found that the matter of financial qualification extended to matters of health and safety so that question need not be answered.

\section{Narrative Testimony.}

During the hearing the PRDC introduced the testimony of its witnesses in narrative form - that is, by prepared written statements. Such procedure is encouraged in the Commission regulations and is authorized by the Administrative Procedure Act, but with the requirement that the witness be made available for such cross-examination as may be required for a full and true disclosure of the facts, so that the interest of any party will not be prejudiced. ${ }^{44}$ Thus, as to that testimony which was given by witnesses whom the PRDC made available for cross-examination, the procedure appears entirely proper.

However, the intervenors objected that many exhibits included in such testimony, i.e., scientific reports, were authored by persons who were not made available by PRDC for cross-examination. Such exhibits clearly constitute hearsay or opinion evidence and, while their admission may not be objectionable per se, a fair hearing seemingly should include the availability of their authors for cross-examination. The regulations give each party the right to subpoena witnesses ${ }^{45}$ and the intervenors thus might have compelled the presence of such exhibit authors as they desired to cross-examine. However, this could shift to the intervenors the expense of attendance of PRDC witnesses-a situation of dubious fairness.

\section{Restricted Data.}

Under the act and the regulations, much scientific and technical data is classified as restricted data and is withheld from general publication. ${ }^{46}$ The Commission is directed to declassify such restricted material where this can be done without undue risk to the coinmon defense and security. ${ }^{47}$ Nevertheless, information of power reactor desigu and operation often has certain direct or indirect bearing upon military application and thus remains classified.

Both the act and the regulations recognize that restricted data may be involved in hearings. ${ }^{48}$ Accordingly, the regulations provide for access to restricted data by parties to a hearing who have obtained the appropriate security clearance. However, in the PRDC hearings counsel for the inter-

44 Administrative Procedure Act $\S 7$ (c), 60 STAT. 241 (1946), 5 U.S.C. § 1006(c) (1952); 10 C.F.R. $\$ 2.747$ (a) (Supp. 1956).

4510 C.F.R. $\$ 2.744$ (Supp. 1956).

40 Atomic Energy Act of 1954, § 11r, 68 STAT. 924, 42 U.S.C.A. \& 2014w (Supp. 1957), redesignated $\S 11 \mathrm{w}$ by 71 STAT. 576 (1957).

47 Atomic Energy Act of 1954, $\$ 142,68$ STAT. 941, 42 U.S.C. $\$ 2162$ (Supp. IV 1956).

48 Atomic Energy Act of 1954, $\S 181,68$ STAT. 953, 42 U.S.C. $\S 2231$ (Supp. IV 1956)); 10 C.F.R. Part 2, Subpart H (Supp. 1956). 
venors demanded access to restricted data in the PRDC application without applying for or receiving a security clearance. The information to which access was sought was alleged by the intervenors to relate only to civilian applications of atomic energy, and thus to bear no such relationship to the common defense or security as would warrant restriction of the information under the Commission's security program. Furthermore, the intervenors alleged that widespread distribution to industry of such information under the Commission's access permit program constituted publication and that declassification was therefore required by the act.

No reason was given by the intervenors for their refusal to make application for security clearance. Accordingly, any unfairness which may have resulted to the intervenors from denial of access to such information must be regarded largely as a matter of self-doing. However, the Commission completely declassified over one-lialf of the documents to which intervenors sought access and partially declassified nearly one-half of the remainder. This action by the Commission unavoidably gave certain credence to the intervenors' allegations that the scope of information currently restricted by the Commission is considerably broader than is either necessary or proper.

\section{Disqualification.}

Near the conclusion of the hearing, the intervenors moved to disqualify the Commission Chairman, Lewis Strauss, on ground of bias. Clairman Strauss had made statenients on August 8, 1956, during his attendance at the ground-breaking ceremony for the PRDC, criticizing unnamed persons in Washington who were opposing and attacking the PRDC project because of prejudice against private power. The intervenors said that such remarks were directed to them and indicated a bias on the Chairman's part. The intervenors also complained of a letter, sent in August 1957 by Cliairman Strauss to a member of Congress, in which the Chairman referred to the AEC's contractual obligations to the PRDC. Accordingly, the intervenors requested that the Chairman disqualify limself or, failing this, that the Commission disqualify him.

Although such statements may evidence a personal attitude and predisposition on the Chairman's part, it is doubtful that they indicate sufficient bias to require disqualification. Under sonewhat similar circumstances, the Supreme Court allowed another agency to adjudicate a matter on which members had previously expressed an opinion; the Court indicated it was sufficient if the minds of the menibers were not "irrevocably closed." 49

\footnotetext{
49 Federal Trade Comm'n v. Cement Institute, 333 U.S. 683, 700-01 (1948).
} 


\section{B. Conclusion}

All parties to the hearing now have submitted briefs together with proposed findings and conclusions. The AEC staff has recommended continuing the license in effect. Whether judicial review of the agency's adjudication will be sought remains to be seen. In any event, the hearing has contributed materially to the establishment of a more satisfactory procedure for those hearings which may transpire in the future. 